\title{
Role of Trees in Farm Bunds - A Case study in Balaghat district, Madhya Pradesh, India
}

\section{S. Saravanan}

Silviculture, Forest Management and Agroforestry division, Tropical Forest Research Institute, RFRC (PO), Mandla Road, Jabalpur 482021. Madhya Pradesh, India

Email: saravanans@icfre.org(ORCID ID:0000-0003-3203-2878)

Received: 04 Oct 2021; Received in revised form: 12 Dec 2021; Accepted: 20 Dec 2021; Available online: 31 Dec 2021

(C2021 The Author(s). Published by Infogain Publication. This is an open access article under the CC BY license

(https://creativecommons.org/licenses/by/4.0/).

\begin{abstract}
Agroforestry systems are multifunctional systems that can provide a wide range of economic, sociocultural and environmental benefits. Agroforestry can be particularly important for smallholder farmers because it generates diverse products and services on a limited land area. The tree resource outside the forest (TOF) is a highly diverse and locally different natural renewable resource. In many regions they play a prominent role in securing rural livelihoods viz., provision of small timber, firewood, fodder, fruits, medicinal value, etc.The present study was conducted at Balaghat districct of Madhya Pradesh to study the types of tree species being maintained in farm bunds, potential benefits of trees, reason for maintaining trees in bunds, etc. The study reveled that, farmers' are maintaining around 25 different tree species for various outputs. Marginal farmers are maintaining trees mainly to meet out their daily needs and small and large farmers for future investment. In this paper, the reasons for opting bund planting, level of domestication and adoption and constraints facing by farmers are discussed in detail.
\end{abstract}

\section{Highlights:}

1. This article gives idea about trees are being maintained by farmers in Balaghat district of Madhya Pradesh.

2. Gives an idea about reasons for opting trees in farm bunds, level of domestication and adoption levels in different farming category.

3. Also, deals in details about constraints facing by farmers in TOF.

Keywords - Trees Outside Forests, Domestication, Bund Planting, NTFPs.

\section{INTRODUCTION}

Agroforestry involves raising trees in combination with other agricultural enterprises. providing fodder, fuel, wood, and other products, trees in agroforestry systems promote soil and water conservation, enhance soil fertility and act as windbreaks for nearby crops. Agroforestry is known to have the potential to mitigate the climate change effects through microclimate moderation, conservation of natural resources and creation of additional source of livelihood and income opportunities. Agroforestry is evolved over a period of time and intricately related to human life from generations to generations. The maintenance of trees either on field boundary or near habitat is traditional practices to fulfill day-by-day needs to secure livelihood and this practice scientifically known as agroforestry from last four to five decades.In recent past, we have witnessed that tree species are receiving more and rapid attention in India to achieve the national goal of 33\% green cover, mostly in the form of Trees Outside Forests (TOF) category. TOF have potential to increase social, economic and environmental stability and overall, net farm income (Saravanan, 2017).

As of now about 25 Mha area is under Agroforestry land use in India and supports almost half of the demand of fuelwood, two third of small timber, 70-80\% wood for plywood industry, $60 \%$ raw material for paper pulp and 9- 
$11 \%$ of green fodder requirement of livestock. Although, current average biomass productivity in India is less than 2 tha $^{-1} \mathrm{yr}^{-1}$ but it can be enhanced to 10 tha $^{-1} \mathrm{yr}^{-1}$ through careful selection of compatible tree crop combination not only to bridge the gap in demand and supply but also to make country surplus in plywood, paper pulp and small timber.Deep tree roots also help prevent soil erosion. Agroforestry systems can also be used as carbon sinks within an environment, and to an extent, help counter the effects of continued deforestation on the carbon cycle.

In India, agroforestry is practiced in various ways like tree on field boundary, block plantation; alley cropping, scattered trees in field, home gardens and homestead gardens etc. Among these, bund plantation is very common practice through-out the country.In such conditions, mostly multipurpose tree species is likely to be chosen to plant on field bunds to achieve the benefits like fruits, fibre, fuel wood, fertilizer, food and medicine. In systematic agroforestry, the industrial hub for plywood and pulp has developed Eucalyptus and Poplar based agroforestry system on 8-9 lakh ha area in Tamil Nadu, Andhra Pradesh, Maharashtra, Karnataka, Punjab, Haryana and western Uttar Pradesh. The income obtained from these system are two-three times higher than conventional cropping practice and this has forced farmer to spare fertile land for agroforestry. Poplar based Agroforestry is classical example of this system where in trees are grown alongside the crops/grasses to obtain diverse produce.Agroforestry not only provides environmental services, but also economic gains, as about $65 \%$ of the country's timber requirement is met from the trees grown outside forests (Dhillon et al., 2018).

Demand and supply of industrial wood is elevated at higher pace after the outlawing the harvesting of green timber from the reserved as well as private lands of India through the implementation of National Forest Policy 1988. As per the FSI (2019) reports states that as being $21.67 \%$ of forest area contributes only 3 million cubic meter wood (approximately $6 \%$ ) and remaining 44 million cubic meter wood comes from agroforestry sector of the country. The demand for furniture, paper and small wood has been rising between $8-12 \%$ annually (Shrivastava, 2017).Planting and maintaining trees in farm bunds is a type of agroforestry system, in order to meet the demands of fuel wood, small timber, fodder and other tree products. These trees strengthen economic security of poor farmers in case of disasters and emergencies by selling trees for cash. The effect of trees grown at bunds of cultivated fields on grain yield of wheat, barley, paddy and potato were studied by many authors (Dhillon et al., 1982, 1984; Grandstaffe et al., 1986; Saxena et al., 1990 and Sac-Lee et al., 1992). Therefore promotion of agroforestry is becoming well proven solution in various parts of countries to cater the needs of farming community as well as environmental security.

The present study was conducted in Balaghat district of Madhya Pradesh to study the types of tree species being maintained in farm bunds, potential benefits of trees, reason for maintaining trees in bunds, etc. are discussed in detail.

\section{MATERIALS AND METHOD}

Study area:This study was conducted at Balaghat district of Madhya Pradesh falls under Chhattisgarh plain agroclimatic zone of Madhya Pradesh, with the population of 1.70 million people (Census, 2011). It is a very important cultural center and its geographical coordinates are parallels of East Longitude' $00^{\circ}$ to $81^{\prime} 00^{\circ}$ and $80^{\prime} 30^{\circ}$ to $22^{\prime} 30^{\circ}$ latitude with an elevation of $288 \mathrm{~m} \mathrm{MSL}$. The normal annual rainfall of Balaghat district is $1294.5 \mathrm{~mm}$. About $91.3 \%$ of the annual rainfall received during monsoon season i.e. June to September. The normal maximum temperature recorded during the month of May is $43 \mathrm{C}^{\circ}$ and minimum is $8 \mathrm{C}^{\circ}$ during the month of December. The district is generally covered with Black cotton soils, Sandy loam and lateritic soil.

Sampling procedure and Survey method: A questionnaire was prepared for collecting information from the study area of Balaghat district, Madhya Pradesh. Using this questionnaire relevant information was collected from 450 farmers, comprising each 150 of marginal, medium and large farmers' category which were randomly selected from the study area. Data were recorded from these selected farmers from May - June, 2021. In conformity with the set objectives of the study, a set of preliminary survey schedules has been designed for collection of data for the study. Thus, the final survey schedule has been prepared in a simple manner maintaining logical sequences and necessary adjustments.

Data analysis: The collected data was analysed by 'Garrett scoring Technique' (Garrett and Woodworth, 1969) and presented in the results and discussion part.

\section{RESULTS AND DISCUSSION}

\section{Tree species planted and maintained in farm bunds}

During the extensive survey it was noticed that, about 25 different types of tree species (Table-1) are being maintained in the farm bunds for eight main reasonsviz., fodder, small timber, fuel wood, fruits, timber, NTFP, medicine and green manure.Among the 25 species recorded in bund planting, nine tree species (36\%) belongs 
to Fabaceae family followed by three tree species (12\%) in Myrtaceae family. Among various uses, usage for fuel wood ranked first $(60 \%)$ followed by small timber $(50 \%)$ and least for medicinal use (12\%) (Fig.1). Jharia et al., (2013) also reported that, other than Eucalyptus, some other MPTs including Terminalia arjuna, Terminalia tomentosa, Albizia procera,Mangifera indica, Butea monosperma, Zizyphus

mauritiana, Azadirachtaindica and Gmelina arborea are also plantedin the farm bunds. Farmers of Gujaratprefered and retains tree species of Acacia nilotica, Acacia catechu, Dalbergia sissoo, Mangifera indica, Zizyphus mauritiana and Gmelina arborea along with crops. In Bihar, Dalbergia sissoo, Litchi chinensis and mango are frequently grown on field, but for boundary plantation, Sissoo and Wendlandia exserta are most commonly used. Farmers of Sikkim, grow bamboo species (Dendrocalamus strictus, Bambusa bambos) all along the irrigation channels (Jhariya et al., 2015). Pohjonen and Pukkala (1990) revealed that, Eucalyptus globulus trees are unpalatable to goats, sheep and cattle, thus they have a distinct advantage as boundary planting in Ethiopia.

\section{Reasons for opting bund planting}

The reasons were obtained from farmers and ranked based on 'Garrett scoring Technique' and presented in Table-2 and Fig.2.During survey, reasons were given to farmers and asked them to rank for opting bund planting. The farmers were classified in to marginal, medium and large farmer category and noted the reasons for maintaining trees in farm bunds. Marginal farmers expressed that, meeting their daily needs from trees ranked $1^{\text {st }}$ followed by higher income and future investment with the mean score of 59.84, 56.24 and 54.81 respectively. Least score of 47.13 was goven for the last rank with the reason for efficient land utilization. Medium farmers are expressed that, higher income is the prime reason for maintaining trees in farm bunds with the mean score of 60.42 followed by future investment and promotion of TOF with the mean score of 58.36 and 54.68 respectively. Least score was given to efficient land utilization with the mean score of 49.81. With reference to large farmers' category, future investment recorded $1^{\text {st }}$ reason for adoption of bund planting with the mean score of 62.56 followed by higher income (59.61) and promotion of TOF (55.71). Meeting day to day needs reason registered least score of 45.47 in large farmers' category. Bargali et al., (2004) reported that, small landholders preferred only bamboo and Eucalyptus for bund and boundary plantations to meet their household requirements. Medium and large farmers preferred a number of species (see table) as they are into commercial production and they have better resources in the state of Chhattisgarh.Depommier et al., (2002) articulated that the needs and strategies of small farmers usually correspond to subsistence agriculture with low inputs and, interestingly, a high level of diversification, which includes tree products and services. The multipurpose use of species partly satisfies the basic needs of poor farmers. Saravanan (2021) revealed that, nonavailability of agricultural labour (ranked first in four agroclimatic zones) and higher returns from tree components (ranked first in two agroclimatic zones) registered higher mean score and ranked among other reasons for adoption of agroforestry systems in different agroclimatic regions of Tamil Nadu.

\section{Level of domestication and extend of adoption of bund planting}

The level of domestication and extend of adoption was analysed and presented in Table- 3 with reference to three farming category. The access to quality planting material $(15.1 \%)$ and technical know how on tree cultivation is low in marginal farmers $(15.1 \%$ \& $30.0 \%)$ category compared to medium and large farmers' category (42.9\& 80.2 and $52.9 \% \& 74.7 \%$ ). From this study, it is showing that, marginal farmers' are not in the position to give proper maintenance including protection measures compared to marginal and large farming category. This level of domestication and extend of adoption of bund planting mostly depends on farmers' choice and self interests. Moreover, socioeconoic factors also plays important role in this aspect. Medium and large farmers are easily access to quality planting material and other related services in tree cultivation compared to marginal farmers. Economic status also plays important role in access to elite planting material and technical know how.

\section{Constraints faced by the farmers in adoption of bund planting}

The constraints faced by the farming communities are analysed and presented in Table- 4 and revelead that, most of the farmers are facing constraints in getting quality planting materials $(82.70 \%)$ and this leads to poor growth and form of trees in later stage. Moreover, there is no certified central nurseries in this region for distribution of quality planting material to stakeholders especially to farmers. In the case of technology, non availability of tree cultivation techniques $(88.44 \%)$ and poor forestry extension strategies $(83.33 \%)$ plays major constraints in promotion of TOF in this region. Unlike in agriculture, there is no proper extension mechanasim for forestry in promotion of TOF and also there is no or very limited resources are available in tree cultivation techniques, which are acceable to farmers'. In agroforestry, marketing $(89.11 \%)$ and value chain models are playing major role. Unlike in agriculture, in forestry/agroforestry, there is no 
market intellegience/updated information for farming communities. Moreover, middleman plays a major role $(81.11 \%)$ in procurring the agroforestry products with low cost compared to market rates. Presence of wood based industries near by area also plays a vital role in procurring the agroforestry produces. Unlike in agriculture, tree growers are not considered for bank loan, incentives, crop insurance and other benefits. These are also creating major constraints among tree growers and reduce the interests in TOF.Taimoor Hassan Farooq et al., (2017) reported that lack of technical assistance, proper awareness and water shortage were the major constraints faced by the farmers for planting trees on their farmlands.Monica Mbatha Masibo et al., (2018) revealed that, education, capacity building and training is vital to enhancing the success of agroforestry programmes. The resultas are in tune with Ibrahim et al., (2019) reported that, the major constraints to agroforestry practices were limited use of machineries $(75 \%)$, poor access to credit $(70 \%)$, fast growing nature of trees $(68.3 \%)$ land tenure $(65.8 \%)$ and marketing channels $(62.5 \%)$

\section{CONCLUSION}

From the above study, it showed that, all the farming category are showing interests in maintaing trees in farm bunds for various end uses. Further, the level of domestication and extend of adoption varies according to farmers category and their economic condition. Invariabely, farmers are facing constraints in getting quality planting materials and tree cultivation technologies. Also, there is no regulated market mechanism and value chain for agroforestry products. Farmers will come forward to grow more trees especially in farm bunds, if these constraints will be addressed for the benefit of farming community.

\section{REFERENCES}

[1] Bargali, S.S, Singh, S.P, and Pandya, K.S. 2004. Effects of Acacia nilotica on gram crop in a traditional agroforestry system of Chhattisgarh Plains. Int. J. Ecol. Environ. Sci. 30(4):363-368.

[2] Census of India, 2011. Registrar General and Census Commissioner of India.

[3] Depommier, D, Laurent, J, Cassou, J, Demenois, J, Heurtaux, A, and Grard, P. 2002. Multipurpose trees and agroforestry practices for sustainable development and conservation of environment in South India: linear plantations and living fences in the dry lands of Karnataka and Tamil Nadu. In: Proceedings of National Seminar on Conservation of Eastern Ghats. Tirupati. p: 161-168.

[4] Dhillon, G. S., S. Singh, M. S. Dhillon and Atwal, A. s. 1982. Developing agrisilvicultural practices: studies on the shading effect of Eucalyptus on the yield of adjoining crops. Indian Journal of Ecology, 9: 228-236.

[5] Dhillon, M. S., Singh, S., Atwal, A.S. and Dhillon, G. S. 1984. Developing agrisilvicultural practices: effect of Dalbergia sissoo and Acacia nilotica on the yield of adjoining crops. Indian Journal of Ecology, 11: 249-253.

[6] Dhillon, R. S., Chavan, S. B., Bangarwa, K. S., Bharadwaj, K. K. Sushil Kumari and Chhavi Sirohi. 2018. Eucalyptus based agroforestry system under semi-arid condieion in North-western India: An economic analysis. Indian Journal of Ecology, Vol. 45 (3): 470-474.

[7] Forest Survey of India. 2019. State of Forest Report, 2019 (Ministry of Environment, Forests and Climate Change, N. Delhi), Dehradun, India.

[8] Garrett, H. E and Woodworth, R. S. 1969. Statistics in Psychology and Education. Bombay, Vakils, Feffer and Simons Pvt. Ltd.

[9] Grandstaf, S. W., Grandstaff, T. B, Rathaketta, P., Thomas, D.E. and Thomas, J.K. 1986. Trees in paddy fields in northeast Thailand. In Mortan G. G (ed.). Traditional Agriculture in South Eastasia, Westview Press, 358 p.

[10] Ibrahim, A. O., Adedeji, A. S. and Meduna, P. N. 2019. Constraints facing agroforestry practices among farmers in New Bussa, Nigeria. Journal of Research in Forestry, Wildlife \& Environment, Vol. 11(3).

[11] Jhariya, M. K. Raj, A. Sahu, K. P. and Paikra, P. R. 2013. Neem- A Tree for Solving Global Problem. Indian Journal of Applied Research. 3(10): 66-68.

[12] Jhariya, M. K., Bargali, S. S, and Abhishek Raj. 2015. Possibilities and perspectives of agroforestry in Chhattisgarh. Open access peer-reviewed chapter. doi: $10.5772 / 60841$.

[13] Monica Mbatha Masibo, Joseph Hitimana, Ann Sitienei Yegon and Yuda Odongo Owino. 2018. Challenges Affecting the Adoption of Agroforestry Practices around Chepalungu Forest in Bomet County, Kenya. Asian Journal of Advanced Research and Reports, Vol. 2(1): 1-10.

[14] Pohjonen, V. and Pukkala, T. 1990. Eucalyptus globulus in Ethiopian

Forestry. Forest Ecology and Management. 36:19-31.

[15] Sae-Lee, S, Vityakon, P. and Prachaiyo, B. 1992. Effects of trees on paddy bund on soil fertility and rice growth in northeast Thailand. Agroforestry Systems, 18, 213-223.

[16] Saravanan, S and Nanita Berry. 2021. Agroforestry practices in Tamil Nadu, India - a boon for farmers for livelihood security. Current Science, Vol. 120 (4): 644-653.

[17] Saravanan, S. 2017. Cultivation of Melia dubia cav. - a fast growing native tree species and constraints faced by the farmers in western region of Tamil Nadu. Indian Journal of Agroforestry, 19 (2): 56-60.

[18] Saxena, A. K. Singh, P. K and Singh, B.P. 1990. Effect of mango trees on growth and yield of wheat. In Singh, R.K, Saxena, A.K. and Singh, I. S. (Eds.). Agroforestry: Present status and scope for future development in the farming system, N. D. Uni. of Agri. And Tech. Kumargani, Faizabad, India, pp. 276-287.

[19] Shrivastava, S. 2017. Forest Productivity-Lumber slumber. Down

to 
Earth.https://www.downtoearth.org.in/news/forestproductivi ty-lumber-slumber-57323.

[20] Taimoor Hassan Farooq, Muhammad Farrakh Nawaz, Muhammad Waqqas Khan, Matoor Mohsin Gilani, Supaporn Buajan, Junaid Iftikhar, Norela Tunon and Pengfei
Wu. 2017. Potentials of agroforestry and constraints faced by the farmers in its adoption in District Nankana Sahib, Pakistan. International Journal of Development and Sustainability, Vol. 6 (8): 586-593.

Table-1. List of tree species planted and maintained in farm bund in Balaghat district of Madhya Pradesh

\begin{tabular}{|c|c|c|c|c|c|c|c|c|c|}
\hline \multirow[b]{2}{*}{ Tree species } & \multirow[b]{2}{*}{ Family } & \multicolumn{8}{|c|}{ Main uses } \\
\hline & & Fodder & $\begin{array}{c}\text { Small } \\
\text { timber }\end{array}$ & $\begin{array}{c}\text { Fuel } \\
\text { wood }\end{array}$ & $\begin{array}{c}\text { Green } \\
\text { manure }\end{array}$ & Medicine & Timber & Fruits & NTFP \\
\hline Acacia catechu & Fabaceae & $*$ & $\S$ & $\overline{\mathrm{O}}$ & -- & -- & -- & -- & -- \\
\hline Aegle marmelos & Rutaceae & -- & -- & -- & -- & *** & -- & g & -- \\
\hline Albizia lebbeck & Fabaceae & -- & $\S$ & $\overline{\mathrm{o}}$ & $\Omega$ & -- & $\mathbb{C}$ & -- & -- \\
\hline Albizia procera & Fabaceae & -- & $\S$ & $\overline{\dot{o}}$ & $\Omega$ & -- & -- & -- & -- \\
\hline Annona squamosa & Annonaceae & -- & -- & -- & -- & -- & -- & g & -- \\
\hline $\begin{array}{l}\text { Artocarpus } \\
\text { heterophyllus }\end{array}$ & Moraceae & $*$ & -- & -- & -- & -- & $\mathbb{C}$ & g & -- \\
\hline Azadirachta indica & Meliaceae & -- & $\S$ & $\overline{\mathrm{o}}$ & $\Omega$ & *** & $\mathbb{C}$ & -- & $¥$ \\
\hline Butea monosperma & Fabaceae & -- & $\S$ & $\overline{\text { ó }}$ & -- & -- & -- & -- & $¥$ \\
\hline Cassia siamea & Fabaceae & -- & $\S$ & $\overline{\mathrm{o}}$ & $\Omega$ & -- & -- & -- & -- \\
\hline Dalbergia sissoo & Fabaceae & $*$ & $\S$ & $\overline{\mathrm{o}}$ & $\Omega$ & -- & $\mathbb{C}$ & -- & -- \\
\hline Dendroclamus strictus & Poaceae & -- & $\S$ & $\overline{\mathrm{o}}$ & -- & -- & -- & -- & $¥$ \\
\hline Eucalyptusterticornis & Myrtaceae & -- & $\S$ & $\overline{\dot{o}}$ & -- & -- & -- & -- & -- \\
\hline Gmelina arborea & Lamiaceae & $*$ & $\S$ & -- & $\Omega$ & -- & $\mathbb{C}$ & -- & -- \\
\hline $\begin{array}{l}\text { Leucaena } \\
\text { leucocephala }\end{array}$ & Fabaceae & $*$ & -- & $\overline{\mathrm{o}}$ & $\Omega$ & -- & -- & -- & -- \\
\hline Mangifera indica & Anacardiaceae & -- & $\S$ & $\overline{\mathrm{o}}$ & -- & -- & -- & g & -- \\
\hline Melia azedarach & Meliaceae & -- & -- & $\overline{\mathrm{o}}$ & $\Omega$ & -- & -- & -- & -- \\
\hline Millettia pinnata & Fabaceae & -- & -- & -- & $\Omega$ & -- & -- & -- & $¥$ \\
\hline Moringa oleifera & Moringaceae & -- & -- & -- & -- & -- & -- & $\oint$ & -- \\
\hline Phyllanthus emblica & Phyllantheaceae & -- & -- & -- & -- & -- & -- & g & $¥$ \\
\hline Psidium guajava & Myrtaceae & -- & -- & -- & -- & -- & -- & -- & $¥$ \\
\hline Syzygium cumini & Myrtaceae & $*$ & -- & $\overline{\mathrm{O}}$ & $\Omega$ & -- & -- & $\oint$ & $¥$ \\
\hline Tectona grandis & Lamiaceae & -- & -- & -- & -- & -- & $\mathbb{C}$ & -- & -- \\
\hline Terminalia arjuna & Combretaceae & -- & -- & $\overline{\dot{o}}$ & -- & *** & -- & -- & $¥$ \\
\hline Vachellia nilotica & Fabaceae & $*$ & $\S$ & $\overline{\dot{o}}$ & -- & -- & -- & -- & -- \\
\hline Ziziphus mauritiana & Rhamnaceae & $*$ & -- & -- & -- & -- & -- & $\oint$ & $¥$ \\
\hline
\end{tabular}

* Fodder; $\S$ small timber; ó Fuel wood; $\Omega$ Green manure; ** Medicine; $\mathbb{C}$ Timber; $g$ Fruit; $¥$ NTFP

Table-2: Reason for opting bund planting in Balaghat district, Madhya Pradesh

\begin{tabular}{|c|c|c|c|c|c|c|}
\hline \multirow{2}{*}{ Reasons } & \multicolumn{2}{|c|}{ Marginal farmers } & \multicolumn{2}{|c|}{ Medium farmers } & \multicolumn{2}{|c|}{ Large farmers } \\
\hline & Mean score & Rank & Mean score & Rank & Mean score & Rank \\
\hline Meeting day to day needs & $59.84(112) * 74.6 \%$ & $\mathrm{I}$ & $52.83(80) 53.3 \%$ & $\mathrm{~V}$ & $45.47(68) 45.3 \%$ & VI \\
\hline Higher income & $56.24(104) 69.3 \%$ & II & $\begin{array}{l}60.42(119) \\
79.3 \%\end{array}$ & $\mathrm{I}$ & $\begin{array}{l}59.61(105) \\
70.0 \%\end{array}$ & II \\
\hline Future investment & $54.81(96) 64.0 \%$ & III & $58.36(112)$ & II & $62.56(119)$ & $\mathrm{I}$ \\
\hline
\end{tabular}




\begin{tabular}{|l|l|l|l|l|l|c|}
\hline & & & $74.7 \%$ & & $79.3 \%$ & \\
\hline Less risk and inputs & $52.56(84) 56.0 \%$ & IV & $57.45(88) 58.7 \%$ & IV & $48.25(76) 50.7 \%$ & V \\
\hline Promotion of TOF & $49.63(78) 52.0 \%$ & V & $54.68(97) 64.7 \%$ & III & $55.71(97) 64.7 \%$ & III \\
\hline Efficient land utilization & $47.13(69) 46.0 \%$ & VI & $49.81(72) 48 \%$ & VI & $52.37(85) 56.7 \%$ & IV \\
\hline
\end{tabular}

* The value within the brackets are frequency $(n=150)$, followed by percentage to the frequency.

Table-3. Level of domestication and extend of adoption of bund planting in Balaghat district, Madhya Pradesh

\begin{tabular}{|l|c|c|c|c|c|c|}
\hline \multirow{2}{*}{\multicolumn{1}{|c}{ Reasons }} & \multicolumn{2}{c|}{ Marginal farmers } & \multicolumn{2}{c|}{ Medium farmers } & \multicolumn{2}{c|}{ Large farmers } \\
\cline { 2 - 7 } & Frequency* & Percentage & Frequency & Percentage & Frequency & Percentage \\
\hline Knowledge on tree cultivation & 135 & 30.0 & 238 & 52.9 & 336 & 74.7 \\
\hline Quality planting material & 68 & 15.1 & 193 & 42.9 & 361 & 80.2 \\
\hline Site selection & 52 & 11.6 & 247 & 54.9 & 286 & 63.6 \\
\hline Type of planting material & 74 & 16.4 & 200 & 44.4 & 301 & 66.9 \\
\hline Time of planting & 361 & 80.2 & 395 & 87.8 & 406 & 90.2 \\
\hline Proper spacing & 253 & 56.2 & 382 & 84.9 & 339 & 75.3 \\
\hline Digging pits in correct size & 148 & 32.9 & 273 & 60.7 & 345 & 76.7 \\
\hline Soil mixture & 82 & 18.2 & 225 & 50.0 & 224 & 49.8 \\
\hline Mulching & 41 & 09.1 & 156 & 34.7 & 208 & 46.2 \\
\hline Irrigation & 38 & 08.4 & 127 & 28.2 & 327 & 72.7 \\
\hline Application of fertilizer & 35 & 07.8 & 159 & 35.3 & 184 & 40.9 \\
\hline Plant protection measures & 167 & 37.1 & 259 & 57.6 & 355 & 78.9 \\
\hline
\end{tabular}

* Frequency $(\mathrm{n}=450)$

Table-4. Constraints faced by the farmers in adoption of bund planting in Balaghat district of Madhya Pradesh

\begin{tabular}{|c|c|c|}
\hline Constraints & Frequency $(m=450)$ & Percentage \\
\hline \multicolumn{3}{|l|}{ Inputs } \\
\hline Quality planting material & 372 & 82.70 \\
\hline Cost of inputs like fertilizers & 238 & 52.90 \\
\hline Cost of plant protection measures & 168 & 37.30 \\
\hline \multicolumn{3}{|l|}{ Technology } \\
\hline Non availability of tree cultivation techniques & 398 & 88.44 \\
\hline Poor forestry extension strategies & 375 & 83.33 \\
\hline \multicolumn{3}{|l|}{ Marketing } \\
\hline Non availability of marketing intelligence & 401 & 89.11 \\
\hline Middle man role & 365 & 81.11 \\
\hline Low cost for forestry products at farm gate & 336 & 74.67 \\
\hline \multicolumn{3}{|l|}{ Loan/Credit/Tree insurance facilities } \\
\hline Non availability of tree loan & 247 & 54.89 \\
\hline Non availability of incentives from government & 412 & 91.56 \\
\hline Non availability of tree insurance or lesser information & 351 & 78.00 \\
\hline \multicolumn{3}{|l|}{ Others } \\
\hline Establishment and linking of tree growers association & 365 & 81.11 \\
\hline Creation of value chain models & 369 & 82.00 \\
\hline
\end{tabular}




\begin{tabular}{|l|l|l|}
\hline Easy in timber transport rules & 400 & 88.89 \\
\hline Less support from SFDs towards TOF & 383 & 85.11 \\
\hline Absence of certified tree nurseries for QPM & 348 & 77.33 \\
\hline
\end{tabular}

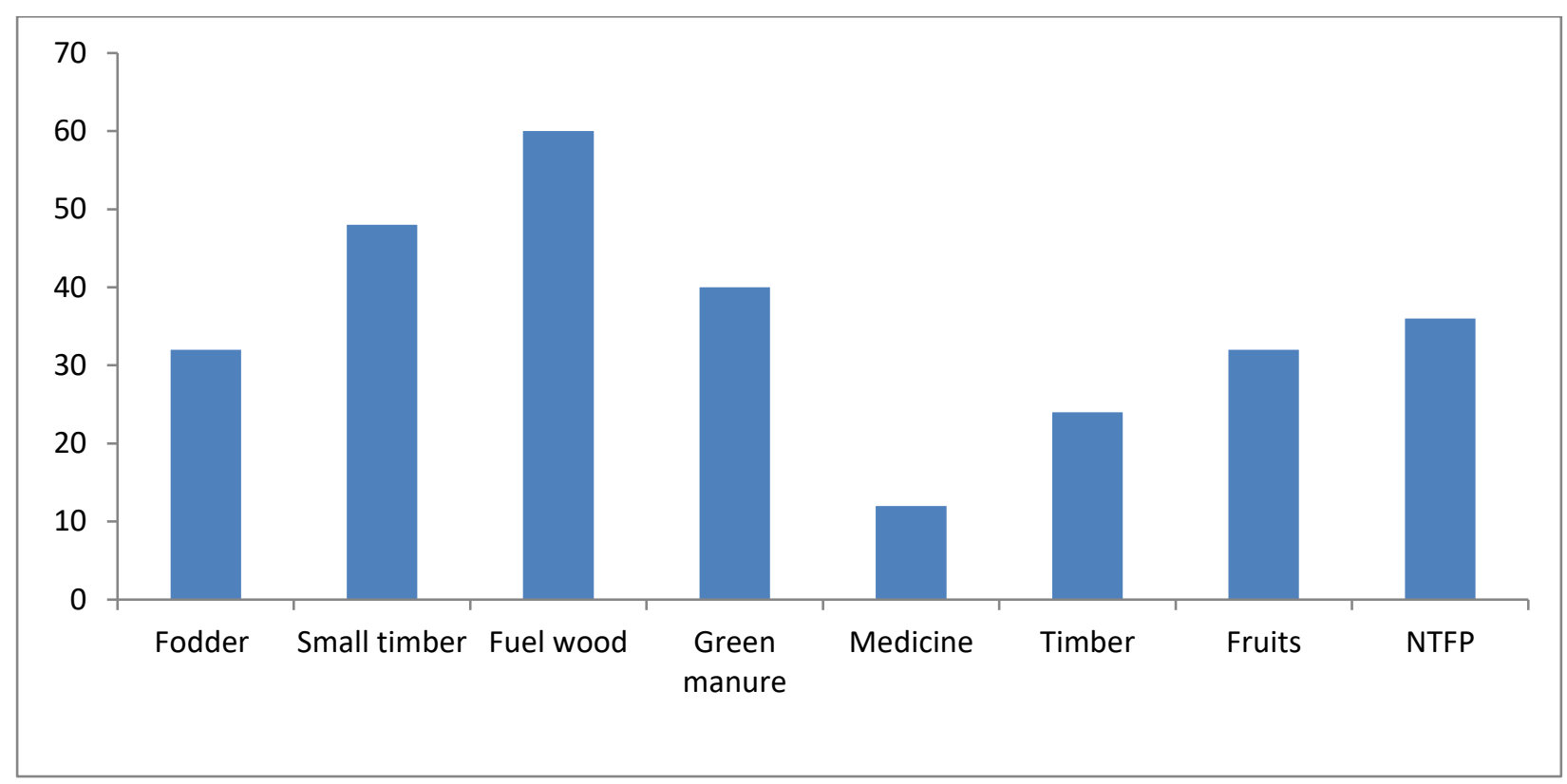

Fig-1: Usage of trees in farm bunds in Balaghat district, Madhya Pradesh

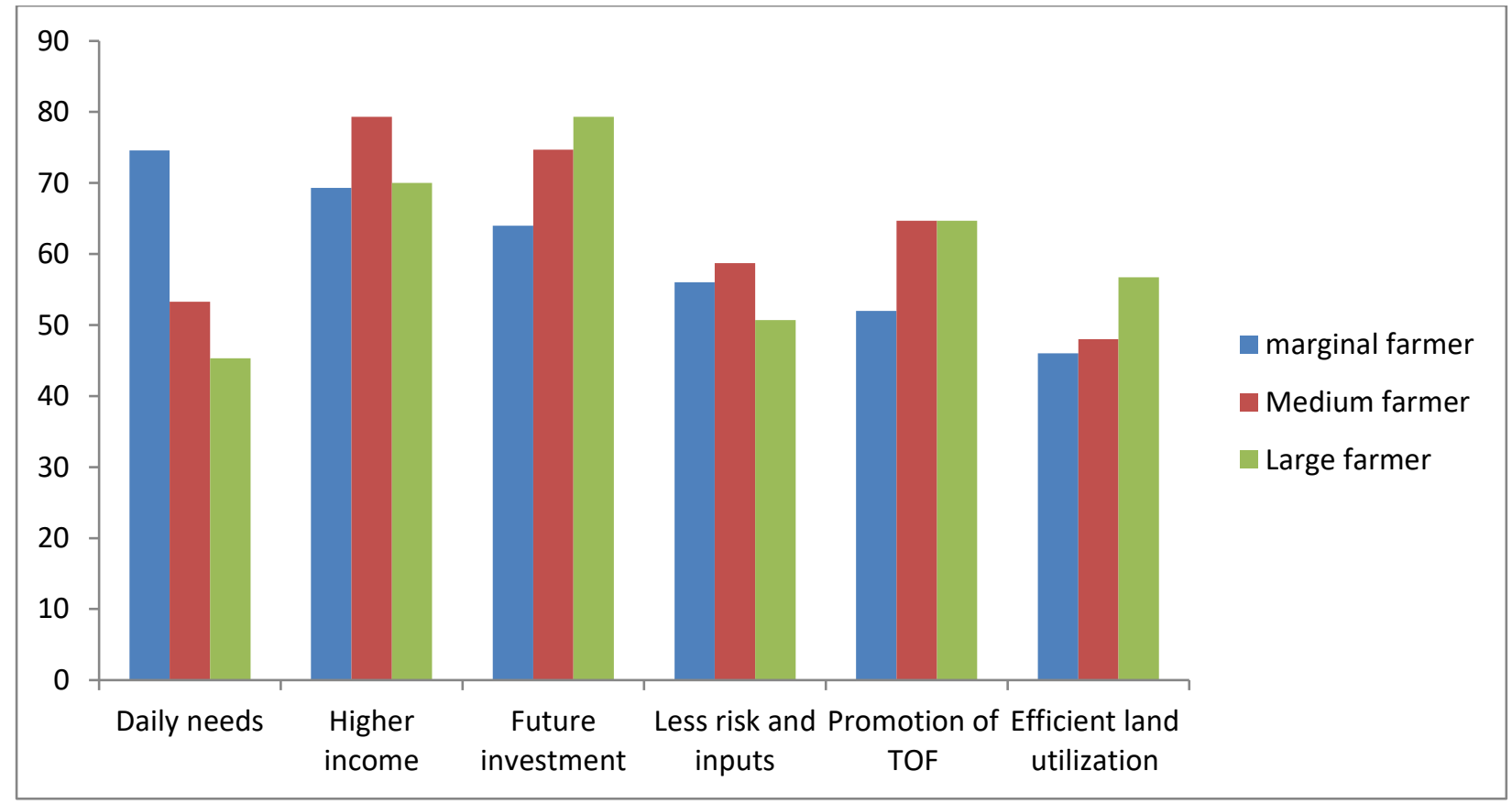

Fig-2: Reason for opting bund planting in Balaghat district, Madhya Pradesh 